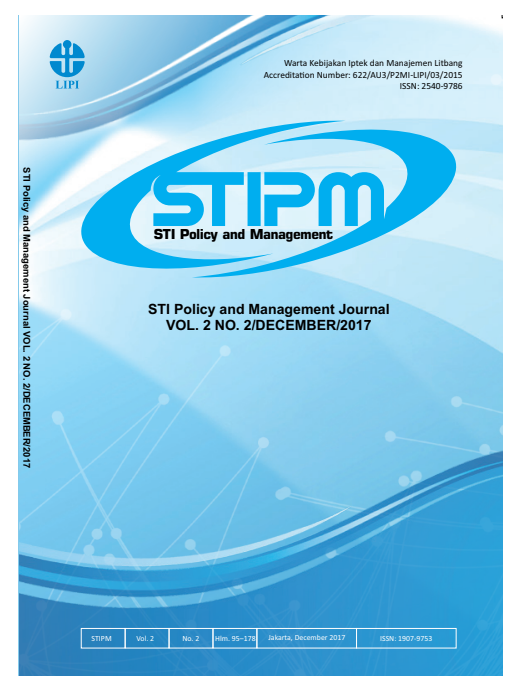

Journal of STI Policy and Management

Publication details, including instructions for authors and subscription information: http://www.stipmjournal.org/

\title{
Mobilizing Science, Technology and Innovation (STI) for Socio-Economic Development: The Experience of Malaysia
}

\section{K. Thiruchelvam}

Former Dean and Professor of the Perdana School of Science, Technology and Innovation Policy, Universiti Teknologi Malaysia

Version of record first published: 15 December 2017

To cite this article: Thiruchelvam, K. (2017). Mobilizing Science, Technology and Innovation (STI) for SocioEconomic Development: The Experience of Malaysia. Journal of STI Policy and Management, 2(2), 127-138 To link to this article: http://dx.doi.org/10.14203/STIPM.2017.79

ISSN 2540-9786 (Print); ISSN 2502-5996 (online)

Accreditation Number: 622/AU3/P2MI-LIPI/03/2015

Full terms and conditions of use: https://creativecommons.org/licenses/by-nc-sa/4.0/

You are free to:

- Share : copy and redistribute the material in any medium or format

- Adapt : remix, transform, and build upon the material

- The licensor cannot revoke these freedoms as long as you follow the license terms.

Under the following terms:

Attribution - You must give appropriate credit, provide a link to the license, and indicate if changes were made. You may do so in any reasonable manner, but not in any way that suggests the licensor endorses you or your use.

$\$$ NonCommercial - You may not use the material for commercial purposes.

(2) ShareAlike - If you remix, transform, or build upon the material, you must distribute your contributions under the same license as the original.

No additional restrictions - You may not apply legal terms or technological measures that legally restrict others from doing anything the license permits.

Notices:

- You do not have to comply with the license for elements of the material in the public domain or where your use is permitted by an applicable exception or limitation.

- No warranties are given. The license may not give you all of the permissions necessary for your intended use. For example, other rights such as publicity, privacy, or moral rights may limit how you use the material.

- If you copy the dataset merely to extract the uncopyrightable data elements would not need permission to do so. However, if you republish the full dataset or using the copyrightable data layers require a permission from PAPPIPTEK-LIPI. 


\title{
JOURNAL OF SCIENCE, TECHNOLOGY AND INNOVATION POLICY AND MANAGEMENT (STIPM JOURNAL), Volume 02, Number 02, December 2017
}

\author{
FOREWORD by EDITOR-in-CHIEF
}

We are pleased to present the STIPM Journal Vol. 2, No. 2, December, 2017. This issue brings together research findings on the adoption of science, technology, and innovation policy and management from Thailand, Malaysia, and Indonesia. This issue also presents a theoritical review on the determinants of enterpreneurial success.

In the original articles of this issue, Poolsak Koseeyaporn et al. presented the Talent Mobility Programme in Thailand. It is a new programme for making relationship between the researchers, who are mostly working at Public R\&D institutions and universities/higher education institutions, and companies. This programme is supporting the researchers to connect, meet, and explore the possibility of having research topics that fulfill both interests of researchers and the companies. The researchers would have a chance to be exposed to the industry's research problems as well as to obtain a level of trust from the companies.

Wati Hermawati and Ishelina Rosaira present the result of an exploratory study on the factors contributing to the sustainability of renewable energy projects in the rural areas. It was indicated that the success of energy technology implementation lays not only in good technology performance and long-term maintenance, but was also highly dependent on six key factors, namely (1) project planning and development; (2) community participation; (3) active communication and beneficiaries; (4) technology maintenance, including workshop and technician availability; (5) project management and institutionalisation; and (6) local government support and networks. The findings from this study provide useful insights to all stakeholders involved in the implementation of renewable energy technology for the rural areas in Indonesia.

Thiruchelvam presents a brief overview on Malaysia's STI achievements, salient features of the nation's national innovation system (NIS), and the key challenges of its NIS. The central theme of the paper is that success in STI is not automatic. It must be made through effective policies in promoting innovation as well as innovations in policy-making itself. Without such commitment for these two sides of innovation policy-making, pouring more resources to the development of STI will be futile.

Ria Hadiyati, et al., discussed the innovation capacity-building in the health sector in Indonesia. Current initiatives to enhance innovation capacity exists by intensifying R\&D consortia in life science, especially vaccine and stem cell. The research capacity in the area of vaccines has been long started from individual research conducted by researchers. It has been continued into research organisations, and then developed into building innovation capacity through R\&D consortia. In areas of stem cell, there is still lack of evidence however, efforts have been made to build innovation capacity through R\&D consortia.

Emyana Ruth and Faiq Wildana compare the management of Indonesian ICT Business Incubators from the perspective of administrators and tenants. The incubation administrators emphasise the 
importance of aspects of skill development, synergy, and seed capital. Meanwhile, from the tenants' perspective, skill development services are considered quite satisfying, either in government, private, or university-owned business incubators. However, emphasising on skill development aspect might lead incubators to provide oversized portion on training activities and susceptible to be trapped as a training institute.

Dyan Vidyatmoko and Pudji Hastuti propose a theoretical framework as a result of the development of theoretical framework, proposed by Kiggundu as well as Lussier and Halabi. The proposed framework is to examine factors affecting the success of entrepreneurship development in Indonesia. Three factors are discussed simultaneously, namely the entrepreneurs, the entrepreneurial firms, and the external environment. Success is represented by three indicators consisting of employment growth, profitability, and survival. Compared to both models, the proposed approach is expected to provide a comprehensive analysis of the factors affecting the success of entrepreneurship development in Indonesia. The results of the study is relevant and useful, both from the academic and practical points of view. It also has practical contribution for policy makers in terms of conceptualising and operationalising appropriate factors for the success of entrepreneurship in Indonesia.

After indexing by Google Scholar, ISJD, and IPI, STIPM Journal is now indexed with DOAJ, BASE, and OCLC World Cat. This has made the journal dissemination wider. We would like to thank all the reviewers for their excellent work and the authors who have kindly contributed their papers for this issue. We are also indebted to the STIPM Journal editorial office at Pappiptek LIPI and the publishing and production teams at LIPI Press for their assistance in the preparation and publication of this issue.

We expect that STIPM will always provide the highest scientific platform for the authors and the readers, with a comprehensive overview on the most recent STI Policy and Management issues at the national, regional, dan international levels.

Jakarta, December 2017

Editor-In-Chief 



\section{JOURNAL OF STI POLICY AND MANAGEMENT}

Volume 2, Number 2, December 2017

\section{LIST OF CONTENTS}

An Empirical Study of Policy Implementation of Thailand Talent Mobility Programme

Poolsak Koseeyaporn, Kittisak Kaweekijmanee, Arum Kitipongwatana,

and Oraphan Wiarachai

Key Success Factors of Renewable Energy Projects Implementation in Rural Areas of Indonesia

Wati Hermawati and Ishelina Rosaira

Mobilizing Science, Technology and Innovation (STI) for Socio-Economic Development:

The Experience of Malaysia

K. Thiruchelvam

Building Capacity for Innovation through R\&D Consortia in Health Projects: From Network Interaction to Systemic Transformation

Ria Hardiyati, Trina Fizzanty, and Erman Aminullah

Management of Indonesian ICT Business Incubators: Administrators' Compared to Tenants' Perspective

Emyana Ruth E. Sirait and Faiq Wildana 149-161

SCIENTIFIC REVIEW

The Determinants of Entrepreneurial Success: A Multidimensional Framework

Dyan Vidyatmoko and Pudji Hastuti. $163-178$ 


\title{
if STI POLICY AND MANAGEMENT

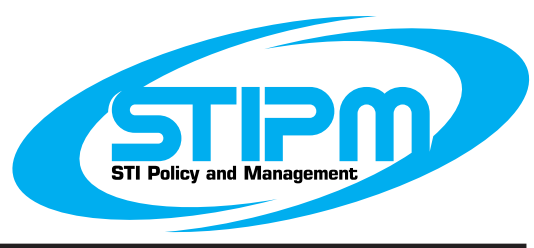

\section{Mobilizing Science, Technology and Innovation (STI) for Socio- Economic Development: The Experience of Malaysia}

\author{
K. Thiruchelvam \\ Former Dean and Professor of the Perdana School of Science, Technology and Innovation Policy, Universiti \\ Teknologi Malaysia
}

\begin{tabular}{lll}
\hline ARTICLE INFO & ABSTRACT \\
\cline { 1 - 1 } $\begin{array}{l}\text { Article History: } \\
\text { Received : 13 January } 2017\end{array}$ & $\begin{array}{l}\text { Malaysia has achieved remarkable economic growth for most parts } \\
\text { of its history, but is finding itself dogged by weak technological } \\
\text { Revised : 05 December } 2017\end{array}$ & $\begin{array}{l}\text { dynamism due to structural features of the economy as well as less } \\
\text { than satisfactory proficiency in science, technology, and innovation }\end{array}$ \\
Accepted : 07 December 2017 & (STI). Despite massive investments in creating STI infrastructure, \\
Available online : 15 December 2017 & & education, physical infrastructure and incentives to support \\
Keywords: & technology upgrading, the stark reality is that the country continues \\
Malaysia & to lag behind the successful latecomers. This paper presents a brief \\
National innovation system & overview on Malaysia's STI achievements, salient features of the \\
STI & nation's national innovation system (NIS), the key challenges of its \\
Innovation & NIS and some recommendations for moving forward. The central \\
Policy making & theme of the paper is that success in STI is not automatic. It must \\
be made to happen through effective policies promoting innovation
\end{tabular}

C2017 PAPPIPTEK-LIPI All rights reserved

\section{INTRODUCTION}

Malaysia has recognised the importance of investing in knowledge-seeking activities in its quest of attaining the status of a high-income, sustainable and inclusive nation by the year 2020. Despite solid public investments in Science, Technology and Innovation (STI) over the past two decades, Malaysia's position in STI is still not satisfactory as evident from several global ranking exercises. This deficiency in innovative capacity is worrying since there are several countries, which are more

* Corresponding Author.

E-mail: kthiru53@gmail.com competitive than Malaysia in terms of land and labour. Many of these countries are catching up fast. Given this intense competition, it becomes imperative that Malaysia reaps dividends from her substantial investments in STI.

This paper provides an overview of the country's macroeconomic performance, followed by a brief summary of the key features of the nation's national innovation system, the innovation performance, the key challenges of Malaysia's Innovation System, some case studies on enhancing the country's innovation performance, responses to the challenges and conclusion.

Malaysia's macroeconomic story since independence in 1957 is truly remarkable. From an 
economy that was entirely dependent on primary commodities, it has successfully navigated over the course of its brief history to become a multisector economy with manufacturing and services propelling its growth to its current emphasis on innovation. Over an extended period, Malaysia has achieved robust economic growth exceeding 7\% per year. Today, with a gross national income (GNI) of USD 11,120 per capita in 2014, Malaysia is placed well in the upper middle income range and is now close to becoming a high-income country. The country's success is not only confined to the economic sphere alone. The country has charted impressive social gains over the past half century. It has built world class infrastructures as well as knowledge infrastructures (universities, research institutes, specialized technology agents, etc.) that are crucial for its future.

While Malaysia has been expanding rapidly for a prolonged period of time, it is not without experiencing periods of turbulence. The impressive economic growth rate since the 1980s came to an abrupt halt following the Asian financial crisis of 1997 which had lasting effects.
While the economy recovered from this crisis, the country failed to achieve the economic growth rate of the pre-crisis era. Malaysia was struck again by the global financial and economic crisis in 2008 with the GDP contracting in 2009 although less severely than a decade earlier. In short, Malaysia has lost its technological dynamism over time. Tracing the past performance of economic growth and its drivers revealed that capital accumulation has been an important contributor of growth in Malaysia. Technological progress, on average, contributed nearly $2 \%$ of the growth (see Table 1). Manufacturing sector registered higher total productivity growth during the period between 1999-2003, but in recent years their growth has slowed down with the service sector (e.g. trade, utilities, and finance) leading to the total factor productivity (TFP) growth (see Table 2). The nation's past sources of growth has declined, the rate of investment has dropped; productivity has slowed down and export market shares have declined. This weakening dynamism underscores the need for Malaysia to become a more innovation-driven economy.

Table 1.

TFP and GDP Growth

\begin{tabular}{ccccc}
\hline Period & Labour & Capital & TFP & GDP \\
\hline $1999-2008$ & 10 & 2.20 & 2.01 & 5.61 \\
$1999-2003$ & 1.22 & 2.18 & 1.88 & 5.24 \\
\hline $2004-2008$ & 1.58 & 2.27 & 2.14 & 5.98 \\
\hline
\end{tabular}

Source: MPC (2009)

Table 2.

TFP (Total Factor Productivity by Sector)

\begin{tabular}{lccc}
\cline { 2 - 4 } & $1999-2008$ & $1999-2003$ & 2004-2008 \\
\hline Agriculture & 1.01 & 1.03 & 1.26 \\
Mining & 1.26 & 1.48 & 0.41 \\
Manufacturing & 2.26 & 3.09 & 1.41 \\
Utilities & 1.63 & 1.13 & 2.13 \\
Transport & 1.36 & 1.27 & 1.44 \\
Trade & 2.12 & 0.40 & 3.82 \\
Finance & 1.87 & 1.72 & 2.02 \\
Others & 1.02 & 3.08 & 0.71 \\
\hline
\end{tabular}

Source: MPC (2009) 


\section{ANALYTICAL FRAMEWORK OF KEY FEATURES OF MALAYSIA'S NATIONAL INNOVATION SYSTEM (NIS)}

Malaysia's quest of achieving its goal of an innovation-driven economy will only be effected if it is being underpinned by strong STI capabilities and a vibrant NIS. A brief description of Malaysia's NIS is given below.

1) Public sector orientation and national focus. Malaysia's STI policies and initiatives can be described as largely public-sector driven besides being supply-side in orientation. Another distinguishing feature of Malaysia's STI landscape is that the design and implementation of STI policies has largely been undertaken at the national level. Similar efforts at local and regional levels have been minimal.

2) Political commitment for STI but weak delivery system. The inclusion of STI in all major policy/development documents since the Fifth Malaysia Plan (1986-1990). Numerous financing and fiscal incentives were introduced to promote innovation. Additionally, substantial investments accorded to human resource development as well as enhancing capabilities of small and medium enterprises (SMEs). Despite impressive array of policies and programmes, their execution has been less than satisfactory.

3) Sound institutional framework but weak management. The framework for STI in Malaysia is sound given adequate institutional structures and mechanisms for coordination. However, weak institutional leadership at all levels has resulted in needless duplications and lack of focus. There are far too many public agencies engaged in STI resulting in lack of focus and thinning of resources. Ministry of Science, Technology and Innovation (MOSTI) which is expected to play the coordinating role in this agenda is too weak to perform this task.

4) Poorly developed linkages. Weak linkages have characterised the innovation landscape in Malaysia although in recent years several initiatives have been made by government research institutions (GRIs) and universities to enhance linkages with industry as well as among public organisations themselves. Weaknesses within industry itself have also compounded these deficiencies.

5) Weak diffusion and weak attention to enhancing absorptive capabilities. Extension activities are poorly developed for the industrial sector. There is presently no dedicated institution entrusted in the transfer of industrial technology to industry as well as mechanisms to enhance the absorptive capabilities of firms. These deficiencies have led to continued weak technological capabilities among SMEs.

6) Lack of focus. Malaysia's public sector research funding programme is characterised by far too many areas of funding as well as too many schemes. Concentration of efforts is necessary since the country cannot afford to spread its limited resources - both manpower and finance -across a broad front.

7) Concerns over effectiveness of education investments and brain drain. Several concerns have emerged regarding the effectiveness of the education system in producing a workforce that is competent in today's knowledge intensive economy. Many people in industries complain on the deteriorating quality of students being produced, especially by the public universities. Another growing problem is the increasing exodus of talented Malaysians to other countries.

8) Promotion and Popularisation of STI. A number of initiatives have been taken to increase public awareness and participation in STI. Much more needs to be done to create the impression, especially among the young that science is fun and an exciting field to explore.

9) International STI Alliances. Malaysia has shared her STI development experience with countries in the developing world through various platforms such as the Commonwealth Partnership for Technology Management (CPTM), OIC Vision 1441 Secretariat, and 
International Science, Technology and Innovation Centre for South-South Cooperation (ISTIC). However, a critical examination on how the country has benefited from such exchanges or from the various bilateral and multilateral agreements signed has not been undertaken. Indeed, it has been argued that Malaysia should adopt a more strategic approach in forging international collaborations that will advance its STI capabilities.

The challenges described previously reveal that Malaysia still has some ways to go in order to catch up with its competitors who are all moving rapidly ahead in the STI proficiency ladder. The principal actors in Malaysia's NIS are largely government or government-linked corporations (GLCs). Figure 1 illustrates the key actors in Malaysia's NIS.

\section{RESULTS}

Malaysia's STI performance-for example in terms of R\&D intensity, R\&D personnel, patents applied and publications-has improved over the past decade. Despite this upbeat trend, the country's performance pales in comparison with countries such as Republic of Korea, Taiwan or Singapore. This section provides an overview of Malaysia's innovation performance.

\section{a. Knowledge Creation through R\&D}

Spending on R\&D in Malaysia has increased by more than twenty-fold over the past two decades from about MYR 0.5 billion in 1996 to reach almost MYR 10.6 billion in 2012. The country's $R \& D$ intensity ( $R \& D$ expenditure relative to GDP) stood at $1.13 \%$ in 2012 -almost double the level achieved in 2006 (see Table 3). Industry $\mathrm{R} \& \mathrm{D}$ intensity has declined to $64.45 \%$ from $71.8 \%$ in 2006 reflecting sharply increased $R \& D$ expenditure by public research institutions and public institutions of higher learning. Despite this decline in proportion, industry's actual expenditure on R\&D in 2012 has increased by almost $60 \%$ from the 2008 total. R\&D contributions by SMEs are still insignificant at $8.0 \%$.

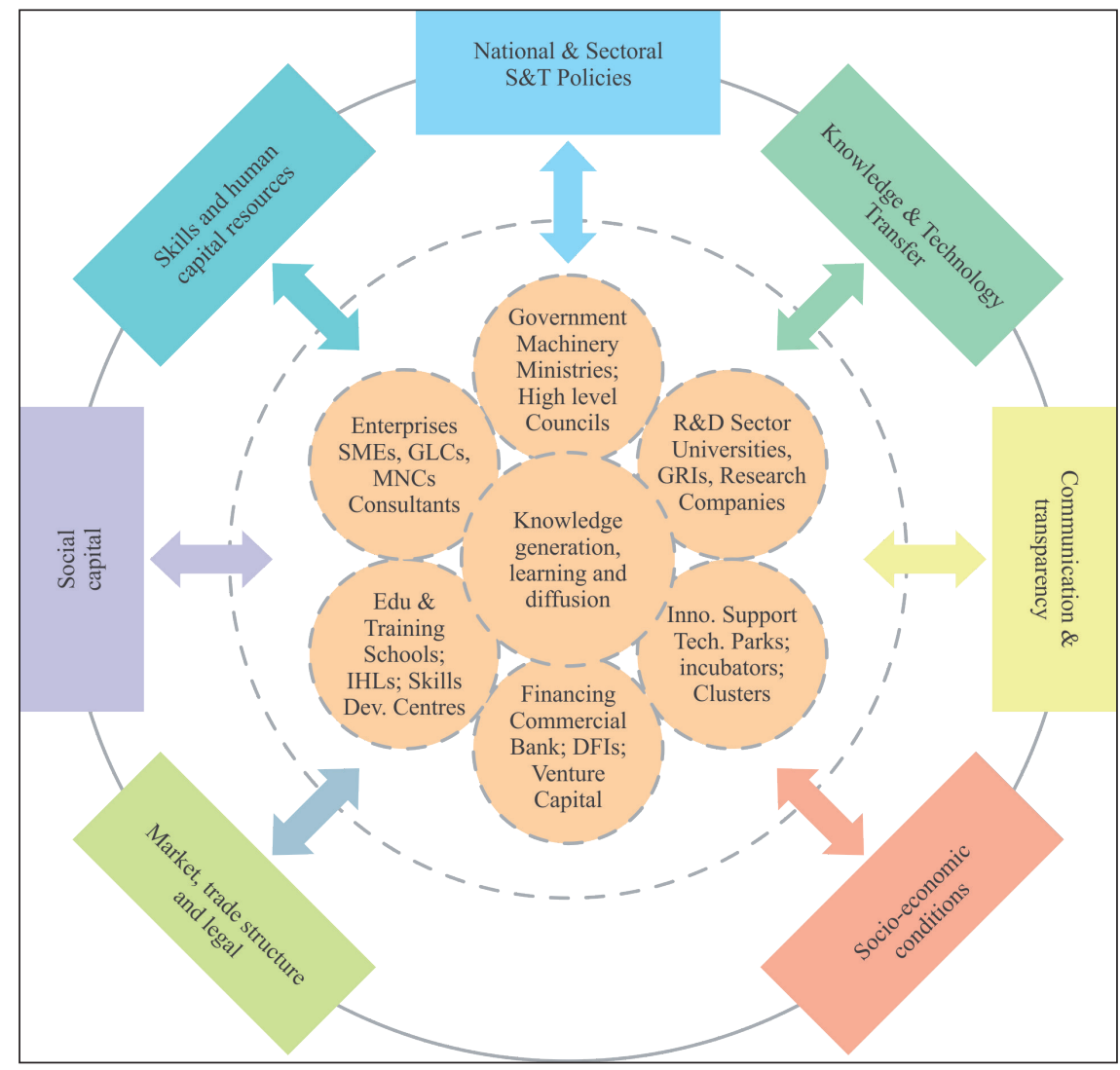

Source: Thiruchelvam et al. (2013)

Figure 1. Key Actors of Malaysia's NIS 


\section{b. STI Human Resources}

The number of $R \& D$ personnel has increased markedly by more than 10 fold from 9,233 in 1996 to almost 104,000 in 2012. Similarly, the number of researchers per 10,000 labour force rose impressively from 5.1 in 1996 to 57.45 in 2012 (see Table 4). The total full time equivalent (FTE) of research personnel in 2012 has recorded a massive increase in tandem with the increase in the R\&D personnel, particularly in the institutions of higher learning. The number of women researchers is increasing and they constitute a significant $50 \%$ of the total number of researchers in the country. Almost $88 \%$ of the country's research personnel are in the public sector (universities and Government Research Institutions (GRIs)).

\section{c. STI Outputs and Outcomes}

Malaysia's total international publications output increased exponentially from $2001(1,029$ publications) to 2014 (15,915 publications) with clear spikes of growth in the years 2004 $(57.25 \%)$ and 2008 (51.19\%). However, the publication growth rate of articles and proceedings decreased during the period 2011 (34.62\%) to 2014 (5.98\%). Articles and proceedings output and growth data is provided in Table 5. Despite the impressive expansion in publications, Malaysia's ratio of citations per article is 5.37, which is still far behind many developing countries such as Philippines, Thailand, Indonesia, and Vietnam. Something of concern is the declining trend of counts of citations since 2012 as well as the low proportion of papers published in high impact publications.

The number of patents granted to Malaysians has increased steadily since 2006 following the corporatisation of the Intellectual Property Corporation of Malaysia (MyIPO). The number of patents filled under PCT has steadily declined since 2011 (see Table 6).

Table 3.

National R\&D Expenditure by Sector, 1996-2012

\begin{tabular}{|c|c|c|c|c|c|}
\hline \multirow{2}{*}{ Category } & \multicolumn{5}{|c|}{ Year } \\
\hline & 1996 & 2000 & 2004 & 2008 & 2012 \\
\hline \multicolumn{6}{|c|}{ R\&D Expenditure (MYR Million) } \\
\hline Total GERD & 549.3 & $1,671.5$ & $2,843.8$ & $6,070.8$ & $10,612.8$ \\
\hline Ratio GERD/GDP (\%) & 0.22 & 0.50 & 0.63 & 0.82 & 1.13 \\
\hline GRI & 108.7 & 417.5 & 296.9 & 603.1 & 730.2 \\
\hline $\mathrm{IHL}$ & 40.4 & 286.1 & 513.3 & $1,188.3$ & 3042.6 \\
\hline Business Enterprise & 400.1 & 967.9 & $2,033.5$ & $4,279.4$ & $6,840.0$ \\
\hline \multicolumn{6}{|c|}{ Proportion of R\&D Expenditure (\%) } \\
\hline GRI & 19.8 & 25.0 & 10.4 & 9.9 & 6.88 \\
\hline $\mathrm{IHL}$ & 7.4 & 17.1 & 18.1 & 19.6 & 28.67 \\
\hline Business Enterprise & 72.8 & 57.9 & 71.5 & 70.5 & 64.45 \\
\hline
\end{tabular}

Source: MASTIC Malaysian Science and Technology Indicators Report (various reports) 1996-2012

Table 4.

Ratio of Researchers to Labour Force/Population, National Headcount \& FTE, 1996-2012

\begin{tabular}{|c|c|c|c|c|c|}
\hline \multirow{2}{*}{ Category } & \multicolumn{5}{|c|}{ Year } \\
\hline & 1996 & 2000 & 2004 & 2008 & 2012 \\
\hline Total Population (Million) & 21.17 & 23.27 & 25.62 & 27.70 & 29.3 \\
\hline Total Labour Force (‘000) & 8616.0 & 9616.1 & 10,856 & $11,028.1$ & 13,100 \\
\hline Researcher (Headcount) per 10,000 labour & 5.1 & 15.6 & 21.3 & 28.5 & 57.45 \\
\hline \multicolumn{6}{|l|}{ Force } \\
\hline Researcher (Headcount) per 10,000 & 2.0 & 6.5 & 9.3 & 11.4 & 25.7 \\
\hline \multicolumn{6}{|l|}{ population } \\
\hline Total R\&D personnel (Headcount) & 9233 & 23,262 & 30,983 & 40,840 & 103,986 \\
\hline Total FTE of R\&D Personnel & 4437.3 & $10,059.67$ & $17,886.55$ & $22,287.29$ & $62,806.81$ \\
\hline
\end{tabular}

Source: MASTIC Malaysian Science and Technology Indicators Report (various reports) 1996-2012 
Table 5.

Yearly Publication Output and Growth Rate

\begin{tabular}{rrrrr}
\hline Year & \multicolumn{1}{l}{ Articles } & Proceedings & \multicolumn{1}{l}{ Total Publications } & \multicolumn{1}{l}{ Growth Rate } \\
\hline 2001 & 960 & 69 & 1029 & \\
\hline 2002 & 1,010 & 93 & 1,103 & 7.19 \\
\hline 2003 & 1,183 & 113 & 1,296 & 17.50 \\
\hline 2004 & 1,378 & 660 & 2,038 & 57.25 \\
\hline 2005 & 1,597 & 686 & 2,283 & 12.02 \\
\hline 2006 & 1,874 & 1,079 & 2,953 & 29.35 \\
\hline 2007 & 2,245 & 1,340 & 3,585 & 21.40 \\
\hline 2008 & 2,905 & 2,515 & 5,420 & 51.19 \\
\hline 2009 & 4,326 & 2,995 & 7,321 & 35.07 \\
\hline 2010 & 5,933 & 2,079 & 8,012 & 9.44 \\
\hline 2011 & 7,798 & 2,988 & 10,786 & 34.62 \\
\hline 2012 & 8,173 & 5,197 & 13,370 & 23.96 \\
\hline 2013 & 9,250 & 5,767 & 15,017 & 12.32 \\
\hline 2014 & 10,499 & 5,416 & 15,915 & 5.98 \\
\hline
\end{tabular}

Source: MASTIC (2015) Bibliometric Study

Table 6.

Yearly Patent Output and Growth Rate, PCT, and MyIPO

\begin{tabular}{rrrrr}
\hline \multirow{2}{*}{ Year } & \multicolumn{2}{c}{ Patents filed under PCT } & \multicolumn{2}{c}{ Patents granted by MylPO } \\
\cline { 2 - 5 } & Number & \multicolumn{2}{c}{ Growth Rate } & Growth Rate \\
\hline 2001 & 22 & 154.5 & \\
\hline 2002 & 56 & -37.5 & 23 & 4.3 \\
\hline 2003 & 35 & 82.9 & 24 & 70.8 \\
\hline 2004 & 64 & 0.0 & 41 & 207.3 \\
\hline 2005 & 64 & 82.8 & 126 & 111.1 \\
\hline 2006 & 117 & 82.1 & -24.1 \\
\hline 2007 & 213 & 11.7 & 266 & 32.7 \\
\hline 2008 & 238 & 89.1 & 202 & -25.7 \\
\hline 2009 & 450 & 5.6 & 268 & 66.3 \\
\hline 2010 & 475 & 5.3 & 199 & -8.2 \\
\hline 2011 & 500 & -1.2 & 331 & -1.6 \\
\hline 2012 & 494 & 19.9 & 304 & 26.4 \\
\hline 2013 & 445 & -1.6 & 299 & 378 \\
\hline 2014 & 438 & & & \\
\hline
\end{tabular}

Source: MASTIC (2015) Bibliometric Study

\section{d. Uneven Innovation across the Regions}

The more developed regions in the country obtained the largest share of about $85 \%$ of the total R\&D budget annually during the period of 1996 to 2008. The budget is concentrated in 4 states, namely Selangor, Kuala Lumpur, Johore, and Penang. This distribution pattern is not surprising since, for example, Selangor is the location of four major public universities besides being home to a number of public research institutes. Also, most of the major firms in the country are located in the Klang Valley (Kuala Lumpur and Selangor). However, there has been a significant shift in the distribution of R\&D budgets in 2008 with the less developed regions accounting for almost a third of the total national R\&D budget. This broad dispersion of the R\&D budget bodes well in the nation's efforts to promote innovative capabilities throughout the country and not confined to any one particular region. 


\section{e. Summary of Malaysia's STI Performance}

Malaysia has improved its STI performance steadily over the past decade. A worrying trend is the low proportion of industry funded research undertaken by the public sector. This low participation rate suggests that collaborations between industry and public research organisations including universities are minimal despite the many efforts to enhance linkages. Another glaring feature of Malaysia's STI landscape is the concentration of scientific activities in the Klang Valley and almost minimal scientific developments in the regions. Although there is strong public support for STI in the country as evident from Malaysian Science and Technology Information Centre (MASTIC)'s biennial public awareness survey findings, some writers (see Hazim, 2004) have cautioned that there are also dissenting views regarding acceptance of modern STI, particularly among the Malay-Muslim community. These undercurrents need to be understood and addressed to ensure that there is greater community support and engagement for Malaysia's STI efforts.

\section{DISCUSSION OF SWOT ANALYSIS}

Benchmarking the overall performance of the economy with that of others, provides useful information on the innovation performance of the country. Malaysia has relatively performed well in dimensions such as infrastructure, health and primary school education, and financial markets. However, as a whole, Malaysia still mirrors an efficiency driven economy due to the lower scores along the dimensions of innovation economy, such as technological readiness, innovation and higher education and training (see Figure 2). It is, therefore, important for Malaysia to catch up in these dimensions to further upgrade herself to mirror the innovation driven economies such as Taiwan, South Korea, and Singapore.

Malaysia's strengths, weaknesses, opportunities, and threats in STI can be briefly summarized as follows.

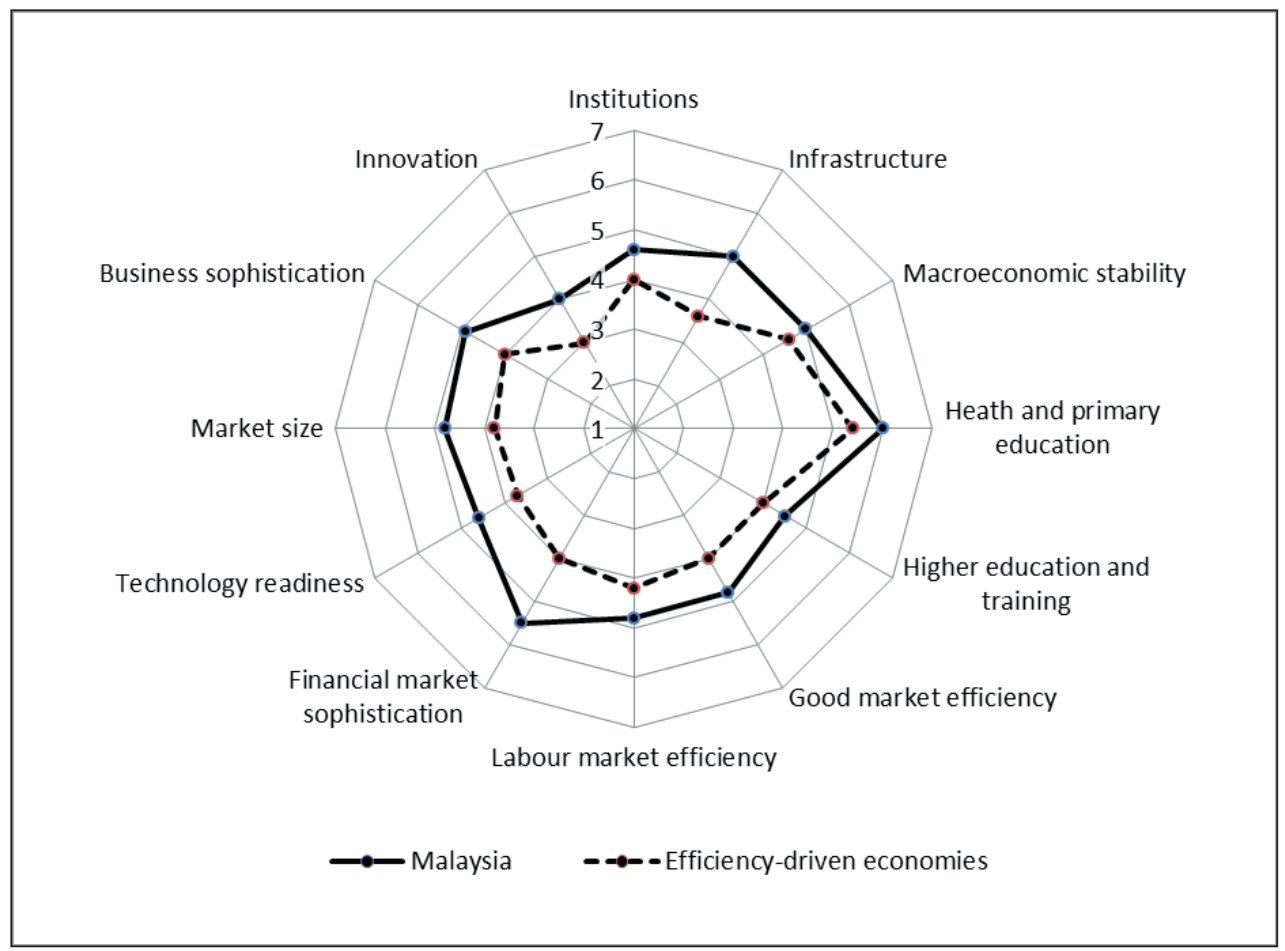

Source: World Economic Forum (2010)

Figure 2. Competitiveness by Major Dimensions 


\section{Strengths}

1) The country has a coherent vision for the development of its STI as envisioned in its various policy documents;

2) There is strong public investment in education and training (see Box 1);

3) There are acknowledged capabilities in particular sectors

\section{Weaknesses}

1) There is poor orchestration of the institutional arrangements to oversee the nation's STI agenda;

2) Poor execution of plans continues to undermine the nation's STI plans;

3) While support for generation and development of STI efforts have assumed impor- tance, diffusion efforts have not received much attention.

\section{Opportunities}

1) The country has a relatively young population with median age of 28 years;

2) Malaysia can exploit its cultural linkages with booming China and India as well as growing Muslim market;

3) Leveraging the sizeable Malaysian diaspora. Box 2 describes the initiative by the government in enticing the Malaysian diaspora to return to the country.

\section{Threats}

1) Competition from emerging economies;

2) Increasing brain drain;

3) Racial polarisation and religious extremism

Box 1.

Expanding and Enhancing Higher Education

Prior to 1969 , there was only one university to service the country. Since then, the number of public universities has increased to 20 in 2008, while there are presently 51 private universities operating in the country. The government launched two plans-namely the National Higher Education Strategic Plan (NHESP) Beyond 2020 and the National Higher Education Action Plan (NHEAP) - to guide the country in its expansion of the higher education sector. Important reforms in terms of funding and governance have been introduced with the goal of strengthening quality and delivery, and fostering excellence in higher education. These reforms are already showing signs of change and important results have been achieved, notably in terms of higher education enrolment rates (at all levels) as well as in terms of enhanced R\&D personnel and the research performance of public universities, among other major achievements. Challenges remain in terms of governance (e.g. autonomy) and relevance to industry (connecting with demand), as well as growing funding constraints. The latter relates to the new obligations for HEls to diversify their sources of funding and find ways to enhance their impact on the economy and society.

Source: OECD (2016)

Box 2.

Malaysian Diaspora and the Role of TalentCorp

The outflow of Malaysian talent is increasing. It is estimated that about $4 \%$ of the country's population resides overseas, approximately $40 \%$ in Singapore. Malaysia's brain drain is intense relative to a narrow skill base. One out of ten Malaysians with a tertiary degree migrated in 2000 to an OECD country - this is twice the world average. The Malaysian diaspora is large and expanding. Our conservative estimate puts the worldwide diaspora at one million people in 2010. The diaspora has grown rapidly: it almost quadrupled over the last three decades.

To remedy this problem, TalentCorp was established in 2011 to retain talent and attract skilled Malaysians abroad to fill the country's growing deficit in skilled manpower. In 2011, 680 applications were approved under the Returning Expert Programme scheme, which was more than double the previous year.

Besides bringing back talent, TalentCorp is also partnering with the Government to enhance the skills level of the workforce and ease transition from school to work place through internship programmes. Additionally, TalentCorp coordinates upskilling programmes for graduates to ensure resources are invested on priority areas. TalentCorp in collaboration with the Public Services Department has introduced scholarship programmes for students who have gained entrance to top universities of the world.

Source: World Bank (2011) 


\section{Responding to the Challenges}

The government has recognized the deficiencies plaguing the STI landscape as described earlier. In 2013, it has adopted a new national STI policy which accords emphasis to 6 thrusts as follows.

1) Advancing scientific and social research, development and commercialization;

2) Developing, harnessing and intensifying talent;

3) Energizing industries;

4) Transforming STI governance;

5) Promoting and sensitising STI; and

6) Enhancing strategic international alliances

Formulating the recommendations is the easy task. Executing them continues to remain the country's Achilles-'heel. A sound institutional and regulatory framework is central to an effective and well-functioning innovation system, including the development of STI. Despite sound structures to steer the nation's STI agenda, Malaysia's STI framework needs to be reinvigorated in order to enhance the execution of policies and empower research institutes and universities to act autonomously to confront the growing complexity of the innovation process. Poor execution of earlier recommendations pertaining to strengthening the governance of the nation's STI framework has continued to undermine the effectiveness of these policies.

The lack of robust STI governance framework has been highlighted by the Academy of Sciences Malaysia in its Science Outlook 2015 report (see Box 3). The report (Academy of Sciences Malaysia, 2015) recommended, among others, the following:

Table 7.

Malaysia's Strengths, Weaknesses, Opportunities, and Threats

\begin{tabular}{|c|c|}
\hline Strengths & Weaknesses \\
\hline 1. A coherent vision for the country; & 1. Weak orchestration of the NIS; \\
\hline 2. Economic and political stability; & 2. Weak demand pull focus as well as weak policies/ \\
\hline 3. Solid public support for STI development; & strategies to forge linkages; \\
\hline 4. Strong public investment in people; & 3. Poor execution of plans; \\
\hline 5. Dynamic private education system; & 4. Poor public-industry linkages in STI; \\
\hline 6. Leading research capabilities in particular sectors; & 5. Poor industry extension activities; \\
\hline 7. High level initiatives to build bridges with industry; & 6. Low absorptive capacity of the SMEs; \\
\hline 8. Good natural resource endowments; & 7. Little competition in some sectors; \\
\hline 9. Sound infrastructure; & 8. Bureaucratic management of support schemes; \\
\hline 10. Cultural diversity; & 9. Poor financing of early stage investments; \\
\hline 11. Islamic leadership credentials; & 10. Weak diffusion of STI efforts; \\
\hline 12. Rich biodiversity. & $\begin{array}{l}\text { 11. Poor quality of education and low ratio of educated } \\
\text { workforce. }\end{array}$ \\
\hline Opportunities & Threats \\
\hline 1. A relatively young population; & 1. Competition from emerging economies; \\
\hline 2. Exploiting cultural linkages with booming China and India; & 2. Increasing brain drain; \\
\hline 3. Harnessing Islamic credentials with growing Muslim market; & 3. Rapid developments in the frontier technologies; \\
\hline $\begin{array}{l}\text { 4. Diversification of trade and production towards more } \\
\text { knowledge-intensive goods/services; }\end{array}$ & $\begin{array}{l}\text { 4. Regional concentration of innovation capabilities; } \\
\text { 5. Continued dependence on low growth economies; }\end{array}$ \\
\hline $\begin{array}{l}\text { 5. Increasing engagement of SMEs in more innovation driven } \\
\text { strategies; }\end{array}$ & $\begin{array}{l}\text { 6. Continued preoccupation with distributive goals of } \\
\text { New Economic Policy; }\end{array}$ \\
\hline 6. Growing demand for frugal innovations; & 7. Global downturn; \\
\hline 7. Harnessing indigenous biodiversity Potentials; & 8. Racial polarisation and religious extremism. \\
\hline 8. Leveraging the sizeable Malaysian diaspora. & \\
\hline
\end{tabular}

Source: Thiruchelvam et al. (2013) 
Box 3.

Recommendation by Academy of Sciences Malaysia for Effective STI

Governance

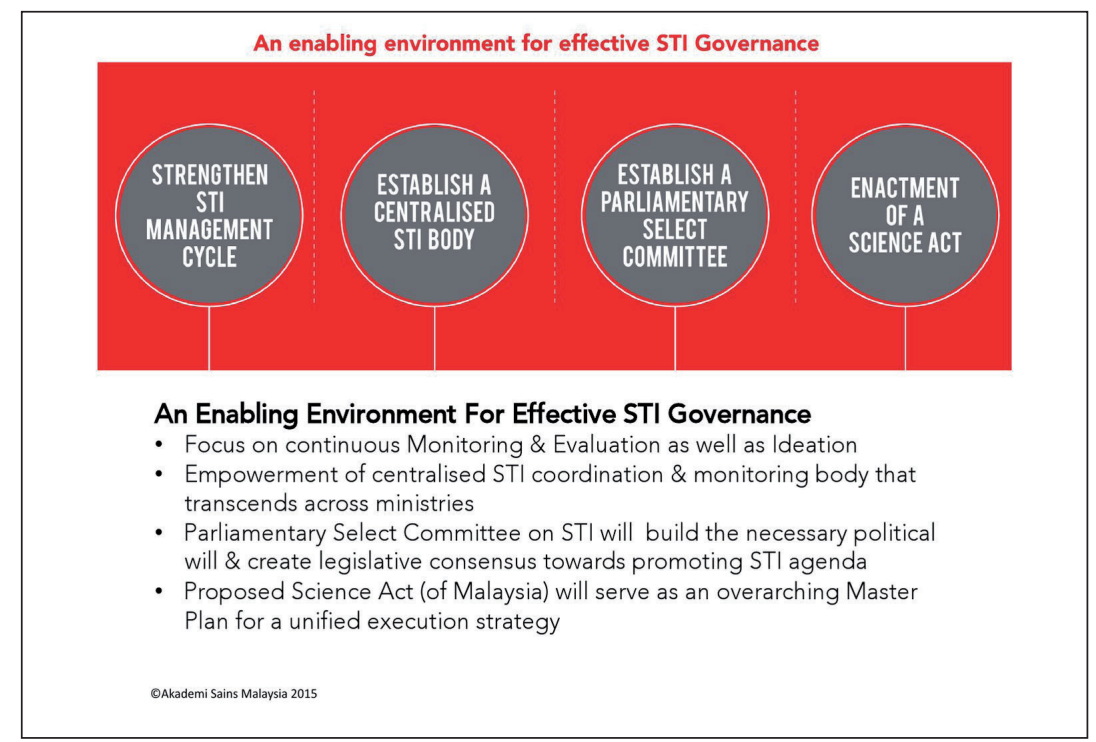

Source: Academy of Sciences Malaysia (2015)

1) Establish a centralized STI body;

2) Establish a parliamentary select committee on STI;

3) Enactment of an STI Act;

4) Strengthen the STI management cycle.

These recommendations on governance are intended to address the weaknesses inherent in Malaysia's STI landscape. A recent report by OECD has also highlighted the problem of multiple actors and needless duplications in Malaysia's innovation system. It also noted that the capacity to implement and deliver the recommendations of the various policies and programmes appear limited. The reasons for this deficiency can be traced to various levels from inadequate governance, lack of political sustainability, insufficient capabilities of middle management administrators as well as their 'distance' from the beneficiaries and operators of their policy. Another factor undermining Malaysia's weak innovation performance is the poor monitoring and evaluation system at the core of the nation's STI policy making. Without such an effective feedback system, all the best STI policies and plans as well as the resources allocated towards the achievement of the stated goals will prove futile.

\section{CONCLUSION}

This paper has traced Malaysia's remarkable macroeconomic success since attaining independence in 1957. From an economy that was entirely dependent on primary commodities, it has successfully transformed over the course of its brief history to become a multi-sector economy with manufacturing and services propelling its growth to its current emphasis on innovation. It has achieved robust economic growth for most parts of its history, but is finding itself dogged by weak technological dynamism due to structural features of the economy as well as poor governance of its STI. Lacklustre investments in high technology and poor educational levels in its workforce are undermining its ambitions of becoming an innovation driven economy. Such ambitions are also being weakened by a serious outflow of talent to other countries.

The government recognises that Malaysia's present proficiency in STI needs to be further enhanced in order to ensure that the nation is not seriously disadvantaged by the exponential pace in scientific and technological developments 
that we are witnessing today. It has developed various policies and programmes to address its weaknesses as discussed earlier in this paper. The National STI Policy launched in 2013 has identified several recommendations to help steer the nation towards meeting the challenges of the next decade. However, like previous policies, weak execution continues to undermine its impact.

Moving ahead requires that Malaysia needs bold and sustained leadership to implement the measures already identified in various policies to move the STI agenda forward. The business as usual approach will not work. A dynamic NIS does not happen by chance. It is, instead, a product of commitment and leadership among the various stakeholders towards effective and efficient transmission of resources and information underpinned by an environment that engenders openness, diversity, creativity, experimentation, and trust. This paper submits some suggestions towards strengthening the NIS of Malaysia as follows.

\section{Focused and Flexible}

Given the limited manpower and financial resources, Malaysia has to adopt a more focused and flexible approach in managing its STI. Such an approach would involve, among others:

1) According emphasis to value-added activities and initiatives that build upon firms' capabilities as well as the country's traditional strengths;

2) Strengthening and development of clusters;

3) Reduce and restructure number of STI incentives and schemes to be aligned with national priorities;

\section{Autonomy and governance}

A new set of organisational dynamics must underpin public sector organisations. They include, among others:

1) PRIs and universities are given greater operational autonomy than hitherto to enable them to respond more quickly and act more flexibly;
2) Greater industry participation and stake in setting the agendas of PRIs and universities;

3) Implementation of recommendations on governance by Academy of Sciences Malaysia;

4) Performance of public STI programmes to be annually audited and reported.

\section{Connections}

Connections are the essence of any wellfunctioning NIS. Activities aimed at promoting connections among the various stakeholders of the NIS include:

1) Promote network groupings;

2) Enhance industrial diffusion efforts;

3) Strengthen connections with diaspora with emphasis accorded to forging partnerships;

4) Support industry associations' technology development activities;

\section{Equilibrium}

The nation's STI efforts must be balanced, for example:

1) Achieving an appropriate balance between funding basic and market driven research programmes;

2) Developing competencies for the short term as well as for the longer term;

3) Striking a balance between supply-side and demand-led initiatives.

\section{Skills and Society}

STI will not flourish without adequate availability of trained manpower as well as supportive society. Accordingly, it is proposed that:

1) Education system to be reformed to foster creativity as well as development of thinking and language skills;

2) Attractive incentives to be introduced to enhance greater enrollment at post-graduate level for science, technical and engineering education;

3) Existing skills and training delivery system to be reviewed and expanded; 
4) Managerial skills of S\&T public organizations to be constantly enhanced;

5) More enculturation programmes to be introduced to elicit greater societal support for STI.

The key proposals as sketched previously (or FACES) ${ }^{1}$ are not exhaustive in addressing the deficiencies of our NIS. This paper has consistently argued that an effective NIS for Malaysia does not happen by chance. Instead, it must be made to happen not only in terms of policies for innovation, but also, more importantly, innovations in policy-making itself. Without such commitment for these two sides of innovation policy-making, pouring more resources to the development of STI in this country will be futile.

Acronym from the five proposed thrusts

\section{REFERENCES}

Academy of Sciences Malaysia. (2015). Science outlook: Action towards vision. Academy of Sciences Malaysia, Kuala Lumpur.

MASTIC. (2015). National bibliometric survey 2015. Putrajaya: Ministry of Science, Technology and Innovation.

MASTIC. (1998, 2002, 2006, 2010, 2013). Malaysian Sciesce and technology indicators report. Putrajaya: Ministry of Science, Technology and Innovation.

MPC. (2009). Productivity report 2009. Petaling Jaya: Malaysia Productivity Corporation.

Shah, M. H. (2004). A tale of two scenarios in the development of science and technology in Malaysia. In Mohd Hazim Shah (ed) Public policy, culture and the impact of globalization in Malaysia. Kuala Lumpur: Malaysian Social Science Association.

OECD. (2016). OECD reviews on innovation policy: Malaysia 2016. Paris: OECD Publishing. (https://doi.org/10.1787/9789264255340-en)

The World Bank. (2011). Malaysia economic monitor: Brain drain. Bangkok: The World Bank.

Thiruchelvam, K., Chandran, V. G. R., Ng., B. K., and Wong, C. Y. (2013). Malaysia's quest for innovation progress and lessons learned. Petaling Jaya: Strategic Information and Development Research Centre. 